\title{
CONTAMINATION OF FOOD AND DRINKS: PRODUCT LIABILITY IN AUSTRALIA
}

\section{Pelma Jacinth Rajapakse}

\begin{abstract}
This article examines the Australian law determining liability of manufacturers and retailers for injury or death allegedly caused by food and drink products which were spoiled, contaminated, or otherwise in a deleterious condition. Product liability and the issue of negligence associated with consumption of foods or drinks deemed as contaminated form the key points of discussion in this article. The liability of manufacturers, processors, wholesalers and retailers are explored with reference to elements of negligence, breach of express or implied warranty, misrepresentation, and strict liability in tort. Australian case law as it pertains to duty of care, breach, causation, and damage has been established and there are consumer protection and product safety laws at both state and federal levels that provide for those affected by contamination/harmful condition of food and drink products. This article explores examples of negligence as the basis of manufacturer's, processor's and retailer's liability in tort (common law and Civil Liability Act 2003 (Qld)) as well as liability under the federal and state legislation such as the Competition and Consumer Act 2010 (Cth), the Food Act 2006 (Qld) and the Australia New Zealand Food Standards Code). The various defences of contributory negligence of consumers, and obvious risk of injury suffered, as well as those established by manufacturers/retailers in the relevant proceedings are used to show the complexity of this issue. The article concludes with recommendations for consumers and businesses to avoid the risk of food contamination and to maintain food safety.
\end{abstract}

\section{INTRODUCTION}

Food and drink poisoning come under the ambit of product liability, a category of negligence, as highlighted by a number of notable cases. ${ }^{1}$ More recently, the New

\footnotetext{
${ }^{*}$ BCom (Honours), Attorney-at-Law, MA (Econ) (Waterloo, Canada), LLM (Monash), PhD (Griffith), Senior Lecturer in Commercial Law, Department of Accounting, Finance and Economics, Griffith University, Queensland. The author gratefully acknowledges the research grant offered by the Socio Legal Research Centre at Griffith University for this project. The comments provided by Professor of Business Law, Dr Eugene Clark of the Griffith Business School and the valuable research assistance provided by Aaron Beh, Solicitor, Brisbane are greatly appreciated.

${ }^{1}$ Donaghue v Stevenson [1931] AC 562; Barnes v Irwell Valley Waterboard [1939] 1 KB 21, 36 (Greer LJ); McWilliams Wines Pty Ltd v Liaweena (NSW) Pty Ltd [1988] ASC 55695; Effem Foods Ltd v Nicholls [2004] NSWCA 332; Dowdell v Knispel Fruit Juices Pty Ltd [2003] FCA 851.
} 
South Wales Supreme Court held a leading fast food franchisor KFC was liable to pay AU\$8 million in compensation for brain damage suffered by a plaintiff as a result of food poisoning. ${ }^{2}$ There are over 22 million Australian consumers and the Australian Food Safety Council has estimated that approximately five million people are afflicted with some degree of food poisoning every year. ${ }^{3}$

In Australia, prior to legislative reform in the area of product liability, a plaintiff consumer could make a claim either under contract law or common law negligence. ${ }^{4}$ With respect to product liability under common law negligence, all the elements required to hold a defendant food supplier liable had to be established. ${ }^{5}$

Product liability under common law negligence still provides a number of disadvantages. For instance, plaintiffs face difficulties in proving other essential elements of negligence, namely breach of duty and causation. ${ }^{6}$ Also, liability under common law negligence is one of fault liability, as opposed to strict liability. ${ }^{7}$ Part VA of the Trade Practices Act 1974 (Cth) ('TPA') was enacted in 1992, and imposed a regime based on 'strict liability'. ${ }^{8}$ Currently, similar provisions can be found under Schedule 2 of the Competition and Consumer Act 2010 (Cth) ('CCA').

Disappointingly, there is no clear method under the Civil Liability Act 2003 (Q1d) (' $C L A$ ') for determining liability for public authorities with respect to food poisoning. Similarly, the Food Act 2006 (Qld) does not allow for a civil claim for its provisions.'

The purpose of this article is to examine the Australian law determining liability of manufacturers and retailers for injury or death allegedly caused by food and drink products which were spoiled, contaminated, or otherwise in a deleterious condition. Product liability and the issue of negligence associated with consumption of foods or drinks deemed contaminated form the key points of discussion in this article. The liability of manufacturers, processors, wholesalers and retailers are explored with

\footnotetext{
${ }^{2}$ Samaan bht Samaan v KFC [2012] NSWSC 381 (24 April 2012).

${ }^{3}$ Australian Academy of Science, Food Poisoning Liability: When Bugs Have You on the Run $(2013)<\mathrm{http}: / /$ www.science. org.au/nova/030/030key.html $>$.

${ }^{4}$ Watson v Buckley [1940] 1 All ER 174. See also Jocelyn Kellam and Elle McIntyre, 'Legal Perspectives on Food Hygiene' (1999) 10 Australian Product Liability Reporter 76, 76.

${ }^{5}$ Dowdell v Knispel Fruit Juices Pty Ltd [2003] FCA 851 [74].

${ }^{6}$ Frank Hoffman, 'Product Liability Risk Transferal through Insurance' (1997) 8 Australian Product Liability Reporter 25, 25-8. See also Frances McGlone and Amanda Stickley, Australian Torts Law (LexisNexis Butterworths, 2008) 136- 8; Harold Luntz, David Hambly, Kylie Burns, Joachim Dietrich and Neil Foster, Torts: Cases and Commentary (LexisNexis Butterworths, $7^{\text {th }}$ ed, 2012) 373-83.

${ }^{7}$ Burnie Port Authority v General Jones Pty Ltd (1994) 179 CLR 520, 549.

${ }^{8}$ Vera Culkoff and Jocelyn Kellam, 'Effect of Implementation of Pt VA of the Trade Practices Act' (1997) 8 Australian Product Liability Reporter 133, 133. See also Jocelyn Kellam and Madeleine Kearney, 'Product Liability, A Decade of Change' (2001) 12 Australian Product Liability Reporter 49, 49-50.

${ }^{9}$ Food Act 2006 (Qld) s 6(1).
} 
reference to elements of negligence, breach of express or implied warranty, misrepresentation, and strict liability in tort. Australian case law as it pertains to duty of care, breach, causation, and damage has been established and there are consumer protection and product safety laws at both state and federal levels that provide for those affected by contamination/harmful condition of food and drink products.

\section{Addressing Product Liability}

Part II of this article seeks to establish how product liability is addressed under the common law action of negligence and the CLA. Cases that demonstrate how liability is or is not established against manufacturers, retailers and the like will be discussed. In addition, two cases wherein issues were either raised or implied as concerning contributory negligence will be examined.

\section{A Dowdell v Knispel Fruit Juices}

The Federal Court case Dowdell v Knispel Fruit Juices Pty Ltd ${ }^{10}$ relates to product liability, and in particular, food poisoning. ${ }^{11}$ The key issue was whether Peter and Theo Constas, second and third cross-respondents respectively, were liable, either in negligence or under a statutory duty, to Knispel Fruit Juices Pty Ltd ('Nippy's Fruit Juices') for the loss and damage the company suffered due to an outbreak of salmonella. Selway J resolved this question in the negative, ruling instead that Peter and Theo Constas were in breach of the contract they had entered into with Nippy's Waikerie Producers Pty Ltd ('Packing'), resulting in Packing's own breach of contract with Nippy's Fruit Juices. ${ }^{12}$ As will be seen, the main issue as regards the elements of negligence involved the idea of reasonable foreseeability.

\section{Facts of the Case}

In the period between 1 January 1999 and 31 May 1999, the South Australian Department of Human Services received notifications pertaining to 507 cases of salmonella infection. The particular strand of salmonella concerned was Salmonella Typhimurium phage type 135a ('ST 135a'), which causes food poisoning in humans. ${ }^{13}$ The consumption of the Nippy's Fruit Juices' brand of unpasteurised fruit juice was common in many of the instances reported. Strands of ST 135a were ultimately traced to the packing shed that Peter and Theo Constas operated and which had supplied infected oranges to Packing, which in turn supplied the oranges to Nippy's Fruit Juices. In fact, of all the suppliers to Packing, the Constas' packing shed was the only known shed with oranges that tested positive for ST 135a. This led the Court to find that the Constas' packing shed, and in particular the solution in the shed's fungicide tank and wax in the shed's wax tank, were where ST 135a made

\footnotetext{
${ }^{10}$ [2003] FCA 851 (13 August 2003).

${ }^{11}$ Ibid [18].

${ }^{12}$ Ibid [1].

${ }^{13}$ Ibid [18].
} 
contact with the oranges. ${ }^{14}$ Selway identified certain measures that could have been taken in order to prevent the salmonella infection, including the use of a sanitiser in the shed's fungicide tank and wash tank, as well as a regular change of the water in the fungicide tank. ${ }^{15}$ Nippy's Fruit Juices relied on the Constas brothers' failure to undertake these measures in order to establish the latter's liability under the law of negligence.

\section{Issues of Negligence}

Selway J summarised succinctly the elements required to establish liability under the common law action of negligence. This included such elements as a duty of care owed to the individual who incurs damage or injury, a breach of such duty, as well as an established 'causal connection' that links the injury sustained to the breach of duty. Additionally, the damage suffered must not be deemed to be too remote. ${ }^{16}$

The Court highlighted the significance of the role of foreseeability in each of the abovementioned elements. The Court pointed out that reasonable foreseeability does not require a person to anticipate or prepare for events that no reasonable person would expect to happen. ${ }^{17}$ Indeed, it was the issue of reasonable foreseeability, or lack thereof that ultimately led the Court to find no liability on the part of the Constas brothers under common law negligence.

The Court ruled that reasonable persons in the position of the Constas brothers would not have reasonably expected a major food poisoning outbreak to occur simply by virtue of their failure to change the water in the packing shed's fungicide tank more regularly. Additionally, a more frequent change of the water would have been aimed solely at preventing mould damage to the oranges, not addressing any concerns with respect to food poisoning. ${ }^{18}$ As such, it was the issue of foreseeability that ultimately rendered the argument of Nippy's Fruit Juices against the Constas brothers fatal.

\section{B Suthern v Unilever}

In a similar example, the case of Suthern $v$ Unilever Australia Ltd $^{19}$ was an issue for the Supreme Court of the Australian Capital Territory ('ACT') to consider was whether or not the defendant, Unilever Australia Ltd ('Unilever') was liable under negligence, as well as sections $53(\mathrm{a})$ and $74 \mathrm{~B}$ of the $T P A,{ }^{20}$ for injuries suffered by

\footnotetext{
${ }^{14}$ Ibid [33]-[34], [36]-[37].

15 Ibid [47]-[48].

${ }^{16}$ Ibid [74].

${ }^{17}$ Ibid [75].

${ }^{18}$ Ibid [89].

19 [2007] ACTSC 81.

${ }^{20}$ See also CCA Sch 2 s 29, Pt 3-5.
} 
the plaintiff Suthern from consuming ice cream containing mercury. Crispin J ruled in the affirmative, relying interestingly on the legal concept res ipsa loquitur. ${ }^{21}$

On 12 June 1996 Suthern's ex-wife purchased a tub of Streets Blue Ribbon Ice Cream. On the evening of 13 June 1996 Suthern opened the tub of ice cream and made servings for both himself and his children. At that time, Suthern did not notice anything suspicious about the ice cream. However, on the evening of 14 June 1996 Suthern, upon serving the ice cream again, noticed mercury in the form of a 'silver ball,' 'grey streaks' as well as 'tiny dots' in the ice cream. Suthern and his ex-wife subsequently took the ice cream to the Canberra Hospital where it was both medically tested as well as inspected by the police. The tests ultimately revealed that the ice cream was indeed laced with mercury. Suthern started to develop various discomforting symptoms progressively over a period of years from 1996, and by 2007 Suthern described his resultant disability as preventing him from working more than 30 hours per week. ${ }^{22}$

\section{(a) Submissions of Counsel for the Defendant}

Counsel for Unilever submitted that the mercury contamination occurred after the tub of ice cream had left its factory and based this submission on a number of facts. First, of the 21,420 tubs of ice cream produced in the suspect tub's production run, the tub purchased by the Sutherns was the only tub known to be contaminated with mercury. Second, Unilever could find no traces of mercury in its factory's pasteuriser, after dismantling and inspecting the pasteuriser. Third, interviewed employees of the factory could not identify any incident that could have led to the introduction of the mercury into the production run. Fourth, a recall of 4321 tubs of ice cream in the ACT did not reveal any traces of mercury. Counsel for Unilever also relied on Professor Hambley's evidence that, based on his own examinations of the tub, as well as the xrays conducted on the tub, since the mercury was not located within the body of the ice cream itself, Professor Hambley was led to conclude that the mercury was placed inside the tub after the ice cream was frozen. ${ }^{23}$ However, the Court found that Professor Hambley's evidence was not reliable, as four years had passed between when the mercury was first discovered in the ice cream and his own examinations. ${ }^{24}$

Finally, the Court accepted that, on the balance of probabilities, there was a strong basis for the assertion that the mercury had found its way into the ice cream while it was still in the factory. ${ }^{25}$

Relying on Wyong Shire Council v Shirt, ${ }^{26}$ counsel for Unilever submitted that there was nothing to indicate any deficiency in how the ice cream was manufactured, stored

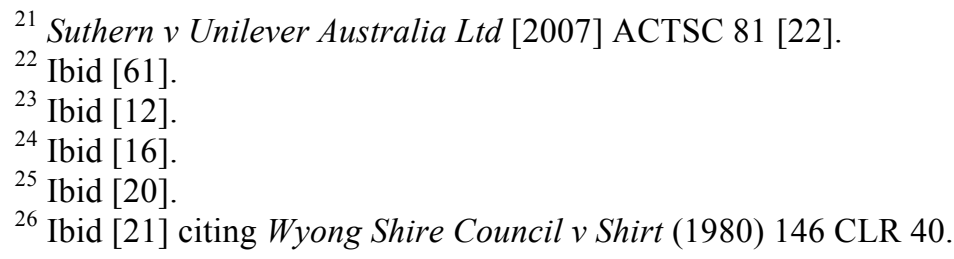


or distributed. Nor was there anything to indicate whether or not measures were available to remedy any deficiencies, and whether those measures would be costly or inconvenient. As it was submitted that the mercury may have found its way into the ice cream through an act of sabotage when the ice cream was already in the supermarket, counsel for Unilever also cited Modbury Triangle Shopping Centre Pty Ltd $v A n z i l^{27}$ to point out that there could be no liability on the part of Unilever for the intervening criminal acts of a third party. ${ }^{28}$

The Court indicated its readiness to accept the submissions of counsel for Unilever, if not for the legal principle res ipsa loquitur. ${ }^{29}$ Citing Cooper $v$ Westpac General Insurance $L t d,{ }^{30}$ the Court outlined three elements needed to invoke res ipsa loquitur. First, there should be no explanation as to the occurrence that caused damage; second, the occurrence must be such that could not occur in the absence of negligence; and third, the thing which gave rise to the occurrence must be under the defendant's control. The Court was convinced that the res ipsa loquitur principle was applicable to this case. There was no explanation as to how the mercury found its way into the ice cream; such an occurrence would not have happened without negligence; and the responsible agent, in this case the factory, was under the control of Unilever. ${ }^{31}$ Therefore, Unilever was found liable under common law negligence in this case.

\section{Graham Barclay Oysters v Ryan}

In this case the action before the High Court concerned three appeals against the decision of the Full Bench of the Federal Court of Australia. These appeals were in relation to potential liability under, among others, common law negligence on the part of growers and distributors of oysters, a company group consisting of Graham Barclay Oysters Pty Ltd and Graham Barclay Distributors Pty Ltd ('the Barclay Group'), as well as the Great Lakes Council and the government of NSW. Such liability arose due to the consumers of oysters grown in Wallis Lake contracting hepatitis A.

The High Court held that neither the Great Lakes Council nor the State of NSW was found to have owed a duty of care to the victim oyster consumers. Additionally, in a narrower majority, Gaudron, McHugh, Gummow and Hayne JJ ruled that the Barclay Group had not breached its duty of care either. ${ }^{32}$ Gleeson $\mathrm{CJ}^{33}$ and Gaudron $\mathrm{J}^{34}$ were in favour of the facts and reasoning set out by Gummow and Hayne JJ, and so the

\footnotetext{
27 (2000) 205 CLR 254.

${ }^{28}$ Suthern v Unilever Australia Ltd [2007] ACTSC 81 [21].

${ }^{29}$ Ibid [22].

${ }^{30}$ [2007] ACTCA 20.

${ }^{31}$ Suthern v Unilever Australia Ltd [2007] ACTSC 81 [23].

${ }^{32}$ Graham Barclay Oysters v Ryan (2002) 194 ALR 337, 354 (Gaudron J), 368 (McHugh J).

${ }^{33}$ Ibid 339 (Gleeson CJ).

${ }^{34}$ Ibid 354 (Gaudron J).
} 
focus for this case will be on the joint judgment of Gummow and Hayne JJ. The following reasons for these rulings will be now be discussed.

\section{$1 \quad$ Great Lakes Council}

According to Gummow and Hayne JJ, establishing a duty of care on the part of a public authority such as the Great Lakes Council involves considering a number of matters. In considering the salient features of the relationship between a public authority and a potential plaintiff, Gummow and Hayne JJ highlighted the need to have both the relevant legislation, as well as the positions that the parties occupied based on the facts established at trial, as points of focus for determining the existence of a duty of care. ${ }^{35}$ Consideration is therefore given to the extent to which the public authority exercised control over the risk of harm that occurred, as well as the extent of vulnerability on the part of those dependant on the public authority exercising its power in a proper manner. Consideration is also given to how consistent the asserted duty of care is within the provisions of the relevant statute, including its scope and purpose. The statutes relied upon by counsel for Mr Ryan were the Local Government Act 1993 (NSW) and the Clean Waters Act 1970 (NSW). In the present case, Gummow and Hayne JJ emphasised the 'fundamental importance' of control on the part of a public authority. ${ }^{36}$ Relying on Agar v Hyde, ${ }^{37}$ their Honours highlighted the fact that if the relevant risk that harm would occur was remote, from both a legal and practical standpoint, then a duty of care could not be established. In distinguishing cases such as Brodie v Singleton Shire Council, ${ }^{38}$ and Pyrenese Shire Council v Day, ${ }^{39}$ the Court ruled that the Great Lakes Council did not exercise control over what it referred to as 'the direct source of harm to consumers', namely the oysters themselves. ${ }^{40}$ Indeed, the Great Lakes Council exercised certain control over landsourced pollution in the Wallis Lake. Such control by the Great Lakes Council could not, however, be linked to a duty of care to the consumers of oysters. This was by virtue of the intervening acts of a third party that the Great Lakes Council had no control over, namely, the oyster growing industry. The Court relied upon Modbury Triangle Shopping Centre Pty Ltd $v$ Anzil $^{41}$ to point out that control over a certain portion of a physical environment is insufficient to found a duty of care where the injury concerned arises from a third party's conduct. ${ }^{42}$ As such, no duty of care could be established between the Great Lakes Council and the infected oyster consumers.

\footnotetext{
${ }^{35}$ Ibid 376 (Gummow and Hayne JJ).

${ }^{36}$ Ibid 377 (Gummow and Hayne JJ).

${ }^{37}$ Agar v Hyde (2000) 201 CLR 552, 562, 564, 581-2.

38 (2001) 206 CLR 512.

39 (1998) 192 CLR 330.

${ }^{40}$ Graham Barclay Oysters v Ryan (2002) 194 ALR 337, 377.

${ }^{41}$ (2000) 205 CLR 254, 263-4, 270, 291-3.

${ }^{42}$ Graham Barclay Oysters v Ryan (2002) 194 ALR 337, 377.
} 


\section{$2 \quad$ State of New South Wales}

The respondent Ryan submitted that the government of NSW had breached its duty to the consumers of oysters grown at Wallis Lake by failing to conduct a sanitary survey of the Wallis Lake region, and require the growers of oysters at Wallis Lake to stop their harvest and sale of oysters following a period of heavy rainfall in the month of November $1996 .{ }^{43}$ For instance, provision was made under the Clean Waters Act 1970 (NSW) and the Clean Waters Regulations 1972 (NSW) for the NSW government to effectively carry out sanitary surveys at Wallis Lake. ${ }^{44}$ With respect to NSW compelling oyster growers to stop their harvests and sales, counsel for $\mathrm{Mr}$ Ryan chose to abandon its reliance on provisions in the Fisheries Management Act 1994 (NSW) and the Food Act 1989 (NSW). Instead, the respondent submitted that the State's agents and officers were able to exercise 'non-coercive' powers that were not specified or given effect by statute, such as the ability to persuade the oyster industry to stop their harvests voluntarily for the sake of preserving public safety. ${ }^{45}$ The respondent made reference to one such instance where shellfish harvesting was temporarily stopped in the month of February 1997 at the State's own initiative. However, Gummow and Hayne JJ could not accept such coercive force as firmly grounding a duty of care on the part of the State, especially where such an asserted duty of care was not owed to the oyster growing industry but rather to the oyster consumers. ${ }^{46}$ As such, NSW owed no duty of care to the injured oyster consumers.

\section{Barclay Group}

The Barclay Group accepted the existence of a duty of care on its part to take reasonable care to make sure that its oysters were fit for human consumption. The issue for the High Court to resolve was whether there was a breach of that duty. As such, Gummow and Hayne JJ cited the judgment of Mason J in Wyong Shire Council $v$ Shirt to point out that such an inquiry involves ascertaining whether or not a reasonable man in the defendant's situation would have foreseen that his or her acts would have given rise to a risk of injury to the plaintiff or to a class of persons to which the plaintiff belonged. If the answer to this question was yes, then it would be necessary to consider how a reasonable person would respond to the risk, which would involve accounting for the risk's magnitude, the probability of the risk occurring, as well as the expenses and inconveniences involved in taking steps to remove the risk. ${ }^{47}$ Once again relying on Wyong Shire Council v Shirt, Gummow and Hayne JJ ruled that the risk of injury to the plaintiffs was not 'far-fetched or fanciful', but rather a risk that was real and thus foreseeable. ${ }^{48}$ The Barclay Group knew of the septic tanks and stormwater drains in Wallis Lake, and also knew of the risk of oysters being contaminated with viruses from human faecal matter. After considering what

\footnotetext{
${ }^{43}$ Ibid 381.

${ }^{44}$ Ibid 381-2.

${ }^{45}$ Ibid 386.

${ }^{46}$ Ibid.

${ }^{47}$ Ibid 387.

${ }^{48}$ Ibid 388.
} 
courses of action the Barclay Group could have taken to alleviate the risk, Gummow and Hayne JJ concluded that taking such action as was available to the Barclay Group would have totally destroyed or at least would have caused major disruptions to the business of the Barclay Group. Relying once again on Wyong Shire Council v Shirt, such action as was available to the Barclay Group could only be justified if the gravity of the risk as well as the probability of its occurrence were great. Gummow and Hayne JJ were convinced that the magnitude of the risk of injury as a result of a hepatitis A outbreak was indeed great, but were not convinced that the probability of such an event occurring was great enough to mandate the Barclay Group taking greater action than it did. ${ }^{49}$ Gummow and Hayne JJ were satisfied with the Barclay Group's response to the risk of oysters being contaminated by viruses, and thus had discharged its duty to the consumers of their oysters.

\section{Forbes $v$ Selleys}

Forbes $v$ Selleys Pty $L t d^{50}$ was an appeal to the NSW Court of Appeal after the appellant had unsuccessfully sued the respondent for damages under section $75 \mathrm{~A}$ of the TPA for negligence. The appellant was unsuccessful at trial because the trial judge was not convinced that the cause of the appellant's illness was due to him inhaling fumes from the product called Selleys Space Invader ('SSI'), which was produced by the respondent.

\section{$1 \quad$ Background Facts}

On 15 February 1997 the appellant used two cans of SSI in order to seal portions of a fireplace. The appellant had followed the instructions for the safe use of SSI, such as ensuring proper room ventilation. In spite of this, the appellant developed headaches on the afternoon of 15 February, which progressed to incoherence, slurred speech and the inability to attend to chores by 16 February. The appellant collapsed while at work on 17 February and was admitted to hospital, where he stayed for two days in a deep coma, having been diagnosed provisionally with encephalitis. The appellant was treated by a specialist neurologist, Dr Darveniza, who was to also give evidence later at trial. Dr Darveniza had made the initial diagnosis of bacterial or viral encephalopathy, but ordered further tests, and upon learning of the appellant's use of SSI from the appellant's wife, contacted the respondent. The respondent provided to Dr Darveniza a Material Safety Data Sheet ('MSDS'). The MSDS provided information on the chemicals found in SSI, the relevant chemical being diphenylmethane di-isocyanate ('MDI'), as well as the potential hazards and effects of inhaling vapour or spray mist from SSI. ${ }^{51}$

\footnotetext{
${ }^{49}$ Ibid 390-1.

${ }^{50}$ Forbes $v$ Selleys Pty Ltd [2004] NSWCA 149.

${ }^{51}$ Ibid [14]-[16].
} 
Although the appellant later recovered and was discharged from hospital, he nevertheless suffered 'severe physical, psychosocial and cognitive loss', in addition to a significant impact on his ability to work.

The key issue at trial concerned the element of causation. ${ }^{52}$ The determination of this issue was twofold. It involved first determining whether the appellant's inhalation of SSI materially caused or contributed to the illness that led to the appellant's hospitalisation. Second, it involved establishing the nature of the appellant's illness, and whether the MDI found in the SSI was the cause of that illness. The evidence thus relied upon was expert evidence, based primarily on issues of science and medicine. The key witnesses at trial for the applicant were Dr Darveniza and Dr Crank, a consultant toxicologist. The witnesses for the respondent were Dr Drew, a toxicologist, Dr Bisbey, an occupational medicine specialist, and consultant neurologist Dr Spira. Given the complexity of this case, Mason P dealt with the appellant's contentions under numerous headings, as follows.

\section{Reasoning of the Primary Judge}

Dr Darveniza did indeed diagnose the appellant with toxic encephalopathy. However, he was unable to rule out other possible diagnoses, such as viral or bacterial encephalitis, although this would have been a less likely diagnosis. The NSW Court of Appeal affirmed Cripps AJ's entitlement to consider the other possible diagnoses as well. ${ }^{53}$

\section{Diagnosis}

The Court of Appeal pointed out that all of the expert witnesses had provided alternatives to the diagnosis provided by Dr Darveniza, and so Cripps AJ could not be compelled to do away with a consideration of these alternatives simply because, on balance, a toxic encephalopathy was the more probable cause. ${ }^{54}$ Indeed, following cases such as Commonwealth $v$ Amann Aviation Pty Ltd ${ }^{55}$ and Sellars $v$ Adelaide Petroleum $N L,{ }^{56}$ if a court must determine on balance whether a particular event has taken place it considers the event as certain if the probability of its occurrence is greater than its non-occurrence. ${ }^{57}$ The Court, however, rejected the notion that the appellant could employ this principle as a basis for arguing that Cripps AJ was in error when he attached relevance to the possibility that the appellant's illness was encephalitis, which was not caused by his inhaling SSI. Given that the issue of causation was based on circumstantial evidence, Mason P, relying on Spigelman CJ's description of expert opinions in Seltsam Pty Ltd $v$ McGuinness ${ }^{58}$ as "strands in a

\footnotetext{
${ }^{52}$ Ibid [19]-[20].

${ }^{53}$ Ibid [36].

${ }^{54}$ Ibid [42].

${ }^{55}$ Commonwealth v Amann Aviation Pty Ltd (1991) 174 CLR 64 [122]-[123].

${ }^{56}$ Sellars $v$ Adelaide Petroleum NL (1994) 179 CLR 332, 365-7.

${ }^{57}$ Forbes $v$ Selleys Pty Ltd [2004] NSWCA 149 [43].

${ }^{58}$ Seltsam Pty Ltd v McGuinness (2000) 49 NSWLR 262, 278.
} 
cable', described the possibility of an alternative cause such as encephalitis as a 'strand in the cable' to which Cripps AJ necessarily had to attach weight. ${ }^{59}$

The Court also pointed out other issues of concern with respect to Dr Darveniza's evidence, namely, the fact that Dr Darveniza had mistakenly assumed that the warnings on the MSDS related to the MDI found in SSI, and also the fact that Dr Darveniza did not profess any expertise in the area of toxicology. ${ }^{60}$

Furthermore, the Court highlighted the necessity of attaching weight to the evidence of Dr Spira and Dr Rawlinson, who both provided evidence of real alternatives to Dr Darveniza's diagnosis that did not favour the appellant. ${ }^{61}$

Besides the evidence of Dr Darveniza, the appellant relied on the evidence provided by Dr Crank, a toxicologist. In order to establish that the appellant's illness was caused by inhaling the MDI found in SSI, Dr Crank made reference to a study of firemen who were exposed to TDI, an isocyanate like MDI, and who demonstrated symptoms similar to those suffered by the appellant. However, Dr Drew, for the respondent, pointed out that MDI and TDI were distinguishable isocyanates, and was not convinced that the study of firemen was proof that the symptoms of TDI could extend to MDI. ${ }^{62}$

\section{$4 \quad$ Methodology of the Trial Judge with Respect to Causation}

The appellant submitted that it had failed at trial by virtue of a flaw in Cripps AJ's legal methodology when resolving the problem of scientific causation. Relying on judgments such as that of Dixon $\mathrm{J}$ as he then was in Betts $v$ Whittingslowe, ${ }^{63}$ the appellant's submission was based on the idea that an evidentiary onus was on the respondent to disprove the finding that it was SSI that caused the appellant's injury. However, the Court could find nothing in the appellant's case that required Cripps AJ to apply Dixon J's judgment. ${ }^{64}$ Regardless, the Court pointed out the highly comprehensive scientific enquiry employed at trial as shedding every light possible on the issue of causation. As such, the onus of proof with respect to causation rested on the applicant.

There was also a submission by the appellant that, because the appellant had smelled a strong odour while applying the SSI, he was exposed to a dangerous amount of MDI. However, Dr Crank was of the view that the only way for the odour to surpass the threshold for odours would have been if the appellant had heated the SSI. As the

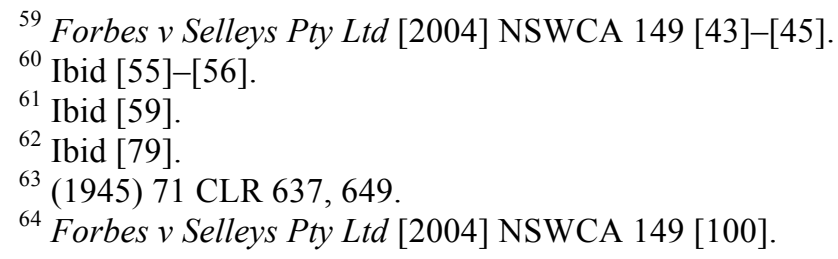


appellant had followed the instructions for applying SSI, which did not involve heating it, the appellant's submission on the SSI's odour could not stand.

The Court described the appellant's case as a 'troubling case', and was not convinced that Cripps AJ had erred at trial, either in fact or law. The Court held that trial judge had not erred by compelling the appellant to prove his case scientifically, and did not fall into any errors of law during the fact-finding process. ${ }^{65}$ The Court was of the view that trial judge was free to accept the evidence of Dr Drew over that of Dr Crank, as the basis for Dr Crank's opinion was a study of firemen, such basis being discredited by Dr Crank's cross-examination and Dr Drew's evidence. ${ }^{66}$ For this reason, and others, the appellant's appeal was dismissed with costs.

\section{Contributory Negligence}

Contributory negligence has been mentioned cursorily in the above cases. In Dowdell $v$ Knispel Fruit Juices Pty Ltd,${ }^{67}$ the Constas brothers asserted that if Nippy's Fruit Juices had suffered damage, it was because of its own contributory negligence. However, the Court held that Nippy's Fruit Juices was not negligent. Following from this, the Court did not see the need to consider the issue as to whether Nippy's Fruit Juices had contributed to its damage by virtue of its own negligence. It may also be suggested that contributory negligence was flagged in Suthern v Unilever Australia $L t d .{ }^{68}$ Counsel for the defendant, early in the proceedings of that case, seemingly hinted that the plaintiff himself had placed the mercury in the ice cream in order to make a false claim.

\section{LIABILITY UNDER THE CIVIL LIABILITY ACT}

As discussed above, when a consumer seeks to hold accountable the manufacturer, retailer, restaurant operator, or the like, for injuries resulting from consumption of such foods, the consumer is required to prove that the food contained a deleterious substance, which, when consumed, caused the illness. The elements required to establish in a common law action of negligence were analysed in the cases noted above. The following section provides the tests for determining the liability under the $C L A$. Each of these elements will be considered in more depth below.

\footnotetext{
${ }^{65}$ Ibid [132].

${ }^{66}$ Ibid [134].

${ }^{67}$ [2003] FCA 851 (13 August 2003).

68 [2007] ACTSC 81.
} 


\section{A Breach of duty of care}

The question of whether a duty of care has been breached is determined by statute in most states and territories. ${ }^{69}$ Section $9(1)$ of the $C L A$ provides that a person does not breach a duty to take precautions against a risk of harm unless:

- 'the risk was foreseeable (that is, it is a risk of which the person knew or ought reasonably to have known)';

- 'the risk was not insignificant'; and

- ' in the circumstances, a reasonable person in the position of the person would have taken the precautions'.

It is worthwhile noting that the statutory test for breach of duty of care is 'substantially declaratory of the common law, ${ }^{70}$ although it is expressed in different terms.

The risk of harm must be reasonably foreseeable. A risk that is reasonably foreseeable is one that is not 'far-fetched or fanciful'. The 'foreseeability of the risk of injury and the likelihood of that risk occurring are two different things'. In Wyong Shire Council $v$ Shirt, Mason J explained the position as follows:

[W] hen we speak of a risk of injury as being 'foreseeable' we are not making any statement as to the probability or improbability of its occurrence, save that we are implicitly asserting that the risk is not one that is far-fetched or fanciful. Although it is true to say that in many cases the greater the degree of probability of the occurrence of the risk the more readily it will be perceived to be a risk, it certainly does not follow that a risk which is unlikely to occur is not foreseeable. ${ }^{71}$

The next consideration is to determine what the reasonable person in the defendant's position would have done. ${ }^{72}$ Section $9(2)$ of the $C L A$ requires the courts to consider the following factors:

- 'the probability that the harm would occur if care were not taken';

- 'the likely seriousness of the harm';

- 'the burden of taking precautions to void the risk of harm'; and

- 'the social utility of the activity that creates the risk of harm'.

\footnotetext{
${ }^{69}$ Civil Law (Wrongs) Act 2002 (ACT); Law Reform (Miscellaneous Provisions) Act 1956 (NT); Personal Injuries (Liabilities and Damages) Act 2003 (NT); Civil Liability Act 2002 (NSW); Civil Liability Act 1936 (SA); Civil Liability Act 2002 (Tas); Wrongs Act 1958 (Vic); Civil Liability Act 2002 (WA).

${ }^{70}$ Halsbury's Laws of Australia (LexisNexis) [300-65] citing Council of the City of Greater Taree $v$ Wells (2010) 174 LGERA 208, 217.

${ }^{71}$ (1980) 146 CLR 40 [13].

${ }^{72}$ Where the defendant has special knowledge or skill, the standard that must be met is that of the reasonable person with that special skill or knowledge: Halsbury's Laws of Australia (LexisNexis) [300-65].
} 


\section{B Causation}

Lastly, the consumer must establish that the breach of the duty of care caused injury or harm to the consumer. Section 11 of the CLA sets out the factors that must be taken into account when establishing causation:

- 'the breach of duty was a necessary condition of the occurrence of the harm' -known as factual causation; and

- 'it is appropriate for the scope of the liability of the person in breach to extend to the harm so caused', known as scope of liability.

Factual causation is determined by applying the 'but for' test. That is to say, would the harm have occurred 'but for' the negligent act or omission ${ }^{73}$ Whilst factual causation is concerned with establishing whether the negligent conduct did in fact cause the harm or damage to the consumer, the scope of liability involves a policy consideration of whether liability should be imposed on the negligent party. ${ }^{74}$

The High Court cases Adeels Palace Pty Ltd $v$ Moubarak ${ }^{75}$ and Sydney Water Corporations $v$ Turano ${ }^{76}$ will be briefly examined in order to illustrate the way in which the statutory requirements and the common law position interact with one another.

\section{$1 \quad$ Adeels Palace}

In Adeels Palace, the appellant ran a restaurant business in NSW. A dispute broke out between patrons of the restaurant and a man who was involved in the fight was hit in the face. The man left the venue and later returned to the venue with a gun. The man proceeded to shoot Mr Najem and Mr Moubarak who each brought proceedings against Adeels Palace for negligence in failing to provide sufficient security at the premises.

At first instance, the District Court found that Adeels Palace had been negligent and awarded damages to Mr Moubarak and Mr Najem. On appeal, the High Court reversed the decisions of the lower courts and found that negligence has not been established. In making its decision, the High Court relied on the common law position and the requirements of the Civil Liability Act 2002 (NSW) ('NSW CLA'). Relevantly, the provisions of the NSW CLA reflect the position in Queensland discussed above.

The High Court considered the three elements required to establish a cause of action in negligence. The High Court found that Adeels Palace owed 'a duty to take reasonable care to prevent injury to patrons from the violent, quarrelsome or

\footnotetext{
${ }^{73}$ Mason J in Wyong Shire v Shirt (1980) 146 CLR 40, 45.

${ }^{74}$ Halsbury's Laws of Australia (LexisNexis) [300-80].

75 (2009) 239 CLR 420.

76 (2009) 239 CLR 51.
} 
disorderly conduct of other persons'. ${ }^{77}$ Thereafter, the requirements of section $5 \mathrm{~B}$ of the NSW CLA were considered in order to determine whether the duty of care had been breached. ${ }^{78}$ The High Court found that the risk of harm was reasonably foreseeable and not insignificant. Adeels Palace 'knew or ought to have known, that there would be violent, quarrelsome or disorderly conduct in the restaurant'. ${ }^{79}$ Interestingly, the High Court declined to consider the issue of whether a reasonable person would have taken certain precautions and elected to deal with causation instead.

The High Court found that the respondents had failed to establish causation under section 5D(1) of the NSW CLA ${ }^{80}$ Factual causation was not established, as there was no evidence to suggest that the presence of security personal would have prevented the gunman from re-entering the premises. ${ }^{81}$ Put another way, the absence of security personal was not a necessary condition of the harm that occurred. Importantly, the High Court noted that whilst the presence of security personal may have changed the outcome of the events, this did not prove factual causation. ${ }^{82}$

\section{Sydney Water Corporation}

In 1981, Sydney Water Corporation ('SWC') laid a water main on land owned by the Liverpool City Council ('Council'). The laying of the water main diverted drainage in the area and caused water logging. In 2001, a tree fell on a car being driven by $\mathrm{Mr}$ Turano and his family. Mr Turano suffered fatal injuries, whilst Mrs Turano and their two children also suffered injuries. It was argued that the tree fell due to water logging in the surrounding area over a period of time, which enabled a pathogen to develop in the trees. Mrs Turano (and her two children) brought proceedings against the Council and SWC for negligence.

At first instance the District Court found that the Council was liable for negligence and that SWC was not liable for negligence. On appeal, the Court of Appeal set aside the verdict against the Council and found that SWC was liable in negligence. On appeal, the High Court reversed the decision of the Court of Appeal and found that negligence had not been established. In making its decision, the High Court relied on the common law position and the requirements of the NSW CLA.

The main issue that the High Court was required to consider was whether SWC owed the respondents a duty of care. Interestingly, SWC accepted that it may be liable to road users for harm or injury caused due to a negligently installed or defective water main. However, it did not owe a duty of care to road users in this case, as the risk of injury was not reasonably foreseeable. More specifically, it was not reasonably

\footnotetext{
77 (2009) 239 CLR 420 [26].

${ }^{78}$ This reflects the position under s 9 of the $C L A$ discussed above.

${ }^{79}$ (2009) 239 CLR 420 [28].

${ }^{80}$ This reflects the position under s 11 of the CLA.

${ }^{81}$ (2009) 239 CLR 420 [48].

${ }^{82}$ Ibid [50].
} 
foreseeable in 1981, that there was a risk of injury to road users in 2001 due to the laying of the water main.

The High Court found that SWC did not owe a duty of care to Mrs Turano and her children. In making its determination, the High Court considered that the laying of the water main in that location 'did not create an immediate risk of harm to road users'. ${ }^{83}$ Further, once the water main had been laid, it was the Council that had control over the land the tree was located on, not SWC. There was therefore no relationship of 'proximity' between SWC and Mrs Turano that supported a duty of care. $^{84}$

Interestingly, the High Court noted that, when determining whether a duty of care exists, reasonable foreseeability 'is bound up with the question of whether it is reasonable to require a person to have in contemplation the risk of injury that has eventuated' ${ }^{85}$ It was therefore not necessary for the exact sequence of events to have been foreseeable, however it must be shown that 'in 1981 it was foreseeable by [SWC] that laying a water main in a bed of sand in this location involved a risk of injury to road users'. ${ }^{86}$

\section{BREACH OF IMPLIED WARRANTIES}

The legislative provisions relating to statutory implied warranties will be considered below. As will be seen, the introduction of the Australian Consumer Law 2010 (Cth) (' $A C L$ ') may have brought improvements to the statutory implied warranties provisions of its predecessor. The changes to the statutory implied warranties provisions in the $A C L$ do not, however, appear to remedy the lack of clarity as to what constitutes 'goods', and there is also no definitive answer as to whether food comes under the ambit of 'goods'. In further discussing these warranties the article will also consider how food is treated by civil liability and food legislation in Queensland, and whether liability is afforded or not.

\section{A Trade Practices Act}

As pointed out by Corones, ${ }^{87}$ the Productivity Commission's Review of Australia's Consumer Policy Framework ${ }^{88}$ ('the Report') served as the driving force behind reforms that led to the creation of the $A C L{ }^{89}$ The Report states that, with respect to defective products, the TPA and corresponding state legislation contained implied

\footnotetext{
${ }^{83}$ (2009) 239 CLR 51 [49].

${ }^{84}$ Ibid [53].

${ }^{85}$ Ibid [45].

${ }^{86}$ Ibid [46].

${ }^{87}$ S Corones, 'Consumer Law: Introduction' (2009) 9 Queensland University of Technology Law and Justice Journal 3, 3.

${ }^{88}$ Productivity Commission, Review of Australia's Consumer Policy Framework, Final Report, 2008.

${ }^{89}$ Corones, above n 87,3 .
} 
statutory conditions that serve to guarantee a minimum standard for the quality and performance of goods. ${ }^{90}$ Each consumer contract had these implied statutory conditions in them. As such, consumers had the option, pursuant to Part V Divisions 2 and $2 \mathrm{~A}$ of the TPA, of making civil claims if such implied statutory conditions were breached.

\section{$1 \quad$ Liability of Suppliers, Manufacturers and Importers under the TPA}

Suppliers, manufacturers and importers faced liability under Part V Divisions 2 and $2 \mathrm{~A}$ of the TPA for loss or damage suffered as a result of goods that are not of a merchantable quality or fit for certain purposes. ${ }^{91}$ For instance, section 71 of the TPA stated that an implied condition that goods are of a merchantable quality exists where a corporation, in the course of business, supplies goods to a consumer. Such an implied condition does not exist if the defect has been specifically drawn to the attention of the consumer before the making of the contract, or when an examination has been conducted that would reveal a defect. ${ }^{92}$ Despite the changes made there remain certain problematic issues with the TPA with critiques put forward by both the Productivity Commission and the Commonwealth Consumer Affairs Advisory Council.

Through the Report, the Productivity Commission highlighted the problematic application of these implied statutory conditions across different jurisdictions, especially with respect to matters such as:

- the excludability of conditions;

- differences in the value of purchases, and thresholds of use when it comes to eligibility; and

- the factors to be taken into account when deciding if the provisions of the relevant consumer legislation are applicable. ${ }^{93}$

The Report also highlighted the concern that the community lacked understanding as to the scope of the implied statutory conditions. In particular, investigations such as those conducted by the Australian Competition and Consumer Commission ('ACCC') revealed that the community lacked an understanding as to the difference between the warranties given by manufacturers voluntarily and the implied statutory warranties. The Productivity Commission recommended the implementation of a 'single national generic consumer law' to eliminate the differences across jurisdictions. ${ }^{94}$

\footnotetext{
${ }^{90}$ Productivity Commission, above n 88, 173.

${ }^{91}$ Ibid.

${ }^{92}$ TPA s 71(1)(a)-(b).

${ }^{93}$ Productivity Commission, above n 88, 173.

${ }^{94}$ Ibid 174.
} 
The Commonwealth Consumer Affairs Advisory Council ('the Council'), in its issues paper on statutory implied conditions and warranties, made mention of the lack of clarity in the implied warranties provisions of the $T P A .{ }^{95}$ This lack of clarity extends to the rights and obligations conferred by the statutory implied warranties provisions of the TPA; for example, whether the term 'merchantability' includes defects that are either cosmetic or minor defects, or is limited to the simple workability of the goods, is unclear. ${ }^{96}$

However, the Council's issues paper does not address the issue as to what constitutes 'goods' in the implied warranties provisions of the TPA, and whether the meaning of 'goods' extends to food. It appears that this issue was not addressed or remedied in the $A C L$.

\section{B Australian Consumer Law}

The $A C L$ 's equivalent of section 71 of the TPA appears to be section 54. Section 54(1)(a)-(b) states that if a person, in trade or commerce, supplies goods to a consumer in circumstances other than sale by auction, a guarantee is in place that the goods are of 'acceptable quality'.

It should be noted that the terminology used in section 54 is different to that used in section 71 of the TPA, which described goods as being of 'merchantable quality'. However, section 54(2) provides a comprehensive definition of the term 'acceptable quality', including that goods must be free from defects and must be safe. Section 54 also makes certain additions that do not appear in section 71 of the TPA, in that a guarantee is not in place where a product that is not of acceptable quality is explained as such through a written notice displayed with the product, or when the consumers themselves cause the goods to not be of acceptable quality. ${ }^{97}$ Besides these additions, and the change in terminology from 'merchantable quality' in the TPA to 'acceptable quality' in the $A C L$, there does not appear to be any other significant change to the implied warranties provisions.

\section{Other Provisions Relating to Warranties against Defective Goods}

Section 102 of the $A C L$ speaks of requirements, prescribed by regulations, for warranties against defects in goods. Section 102(1) states that the regulations may make provision for requirements with respect to the form and content of warranties against defects in goods.

Section 102(2)(a) further states that an individual, when supplying a consumer with goods or services in trade or commerce, cannot provide to a consumer a document

\footnotetext{
${ }^{95}$ Commonwealth Consumer Affairs Advisory Council, Consumer Rights: Statutory Implied Conditions and Warranties (Issues Paper, July 2009) 17.

${ }^{96}$ Ibid.

${ }^{97} A C L$ s $54(5)-(6)$.
} 
that evidences a warranty against defects in the goods if such a document does not comply with requirements as stipulated by the relevant regulations. Section 102(2)(b) states that a direct representation to the consumer to the same effect also comes under the ambit of the prohibition under section 102(2)(a).

A warranty against defects is defined by section 102(3) of the $A C L$ to be a representation made to a consumer with respect to the supply of goods or services that contains conditions, either unconditionally or on specific conditions, regarding the following if the goods or services turn out to be defective:

(a) the repair or replacement of the goods or a portion of the goods;

(b) the provision or repeated provision of services or a portion of them; or

(c) the whole or partial recompense to the consumer.

The application of these components of the relevant laws to the issue of foods will now be presented.

\section{D 'Food' and 'Consumer Goods' under the Australian Consumer Law}

At no point in the $A C L$ is there any specific reference to food or food poisoning. The question then becomes whether or not food would still come under the definition of 'goods' for the purposes of the $A C L$. The term 'goods' has been defined in section 2 of the $A C L$ to include animals, including fish, as well as crops. It may therefore be suggested that food may be included under the ambit of 'goods' for the purposes of section 2. Food may also be included under the ambit of 'consumer goods' in section 2 , which includes goods that are intended or are likely to be used for consumption.

It is interesting to note that, in section 12 of the Food Act 2006 (Qld), the definition of 'food' includes 'a substance or thing of a kind used, or represented as being for use, for human consumption (whether it is raw, prepared or partially prepared)'. As such, although not unequivocally stated in the $A C L$, food may very well come under the ambit of consumer goods for the purposes of the legislation.

Within state legislation there are two key items related to food and consumer protection, namely the Food Act 2006 (Qld) and the CLA, which will now be examined.

\section{E The Food Act}

The Food Act 2006 (Qld) states in section 6(1) that no provision in the Act gives rise to a civil cause of action. Likewise, section 6(2) states that no provision in the Act affects or limits a right or remedy under a civil cause of action. Section 6(3) goes even further, and states that, without limiting section 6(2), compliance with the provisions of the Act does not necessarily indicate that an individual has discharged or breached a civil obligation. 
As can be seen, the Food Act does not concern itself with civil obligations. Rather, the Food Act's objects, as outlined in section 8 (a)-(c) are the following:

(a) To ensure that food being sold is safe and suitable for consumption by humans;

(b) To prevent misleading conduct with respect to selling food; and

(c) To apply the Food Standards Code, which is defined by Section 14(1) of the Food Act to mean the Australia New Zealand Food Standards Code.

The Food Act achieves these objectives by making provisions for licences, safety programs and accreditation of such safety programs, as well as providing monitors and enforcement procedures to ensure compliance with the provisions of the Food Act. $^{98}$

The Food Act also prescribes a number of offences with respect to breaches of the Food Act's provisions. ${ }^{99}$ Section 32 states that a person may face a penalty of up to two years imprisonment if such a person handles food intended for sale in such a way that the person knows, or ought reasonably to know, that such handling would or would likely render the food unsafe for consumption. Section 33 also states that a person may be liable to serve two years' imprisonment if such a person sells food that the person knows, or ought reasonable to know, is unsafe. A person also commits an offence if he or she falsely describes food or sells food that he or she knows, or ought reasonably to know, is falsely described in such a way that a person may suffer physical harm in reliance on the false description.

\section{F Civil Liability Act}

The only time food is specifically mentioned in the CLA is in Chapter 2 Part 3, which contains provisions with respect to food donors and volunteers. A food donor is defined in section 38 of the CLA to mean an entity that, in good faith, donates food, with the intention that the consumer of the food need not pay for the food, for the following purposes: charitable, philanthropic, benevolent, sporting, recreational, educational, political or cultural.

This definition does not include the following entities or people:

(a) An entity that distributes the food to the ultimate consumer directly; or

(b) A volunteer. ${ }^{100}$

\footnotetext{
${ }^{98}$ Food Act 2006 (Qld) s 9(a)-(d).

${ }^{99}$ Ibid ss 32-34, 20(1).

${ }^{100}$ CLA s 38.
} 
Section 38 of the CLA defines a volunteer to be a person who performs voluntary community work, or provides food in the circumstances as specified by section 39(3), which will be discussed in detail below.

\section{G Food Donors}

Food donors enjoy protection from civil liability under section $38 \mathrm{~A}$ of the $C L A .^{101}$ Section 38A(1) states that a food donor is not liable for any harm caused by the consumption of food that the food donor provided under the circumstances mentioned in section $38 \mathrm{~A}(2)$. These circumstances include the following:

(a) That the food was safe for human consumption when the food left the possession of the food donor; and

(b) If the food was required to be handled in a certain way, so that it would remain safe upon leaving possession of the food donor, the food donor told the direct recipient of the food of the handling requirements; and

(c) In the event that the food was only safe for a certain period of time that the food donor alerted the direct recipient of the food as to the amount of time the food would remain safe.

\section{H Volunteers}

Volunteers enjoy protection from liability under section 39(2) of the CLA, which states that a person is not liable for any act or omission when donating food in any of the following circumstances mentioned in section 39(3):

(a) That the donor, who donated the food with the intention that the ultimate consumer of the food would not have to pay for the food, donated the food in good faith and for charitable, benevolent, philanthropic, sporting, recreational, educational, political or cultural purposes; and

(b) When the food left the volunteer's possession the food was safe for consumption; and

(c) If the food was required to be handled in a certain way, so that it would remain safe upon leaving possession of the food donor, the food donor told the relevant community organisation of the requirements for handling the food; and

(d) In the event that the food was only safe for a certain period of time, that the food donor alerted the relevant community organisation as to the amount of time the food would remain safe.

\section{Summary}

\footnotetext{
${ }^{101}$ NSW CLA ss 58A, 58C; Wrongs and Other Acts (Public Liability Insurance Reform) Act 2002 (Vic) ss 31F-31H; Civil Law (Wrongs) Act 2002 (ACT) ss 11A-11B; Civil Liability Act 1936 (SA) s 74A; Volunteers and Food and Other Donors) Protection from Liability Act 2002 (WA) s 8A; Civil Liability Act 2002 (Tas) s 35F.
} 
It is true that the $A C L$ is an improvement on the $T P A$ when it comes to its statutory implied warranties provisions. However, these improvements have not gone so far as to confirm definitively whether the term 'goods' in the statutory implied warranties provisions include food. The definition of 'goods' and 'consumer goods' may suggest that food is included. Likewise, it appears that the definition of 'food' in the Food Act is of assistance in confirming that food is consumed. However, the Food Act only deals with offences relating to food, and its provisions do not give rise to a civil cause of action. Interestingly, the CLA mentions food only in relation to food donors and volunteers, and defines the circumstances where food donors and volunteers escape liability.

\section{RECOMMENDATIONS}

\section{A Reference to Food in the Australian Consumer Law}

The definition of 'goods' and 'consumer goods' should be amended to plainly and unequivocally include food. However, it may be suggested that legislators would not be so inclined to take action on this recommendation for one key reason, namely, that one of the pervading concerns in the law surrounding product liability is the issue of opening the floodgates, and an Australian society excessively inclined toward litigation.

\section{B Opening the Floodgates}

The argument regarding floodgates concerns the effect that numerous claims may have on the administration of justice, namely, the ability of the courts to cope with the amount of claims or false claims that may come before the court, and the difficulty behind contesting such false claims. ${ }^{102}$ There is a concern among the courts, as far afield as Canada, ${ }^{103}$ that the floodgates can be opened to unlimited liability. ${ }^{104}$ Additionally, concerns about an excessively litigious Australian society were also expressed by the Queensland courts during the times of the Ipp reforms. ${ }^{105}$ In Lisle $v$ Brice $^{106}$ Thomas JA made the following comments:

In a compensation-conscious community citizens look for others to blame. The incentive to recover from injury is reduced. Self-reliance becomes a scarce commodity. These are destructive social forces. Also much community energy is wasted in divisive and non-productive work. A further consequence is the raising of

\footnotetext{
102 J Kellam, 'Recoverability of Pure Economic Loss in Product Liability Cases' (2008) 19 Australian Product Liability Reporter 58, 61. See also Johnson Tiles Pty Ltd v Esso Australia Pty Ltd (2003) Aust Torts Reports 81-692.

${ }^{103}$ Norsk Pacific (1992) 91 DLR (4d) 289.

${ }^{104} \mathrm{~J}$ Allsop, 'Bryan v Maloney and other Developments in Relation to the Duty of Care in Tort' (1996) 7 Insurance Law Journal 2.

${ }^{105}$ H Luntz, D Hambly, K Burns, J Dietrich and N Foster, Torts, Cases and Commentary (LexisNexis Butterworths, $6^{\text {th }}$ ed, 2009) 21.

${ }^{106}$ (2001) 34 MVR 206 [4]-[5].
} 
costs of compulsory third party, employer's liability, public risk and professional indemnity insurance premiums. These costs are foisted upon sectors of the public and in the end upon the public at large. I would prefer that these problems be rectified by the development of a more affordable common law system, but in recent times its development has been all in one direction - more liability and more damages.

It may therefore be suggested that these concerns go some way to explaining why section 6(1) of the Food Act is emphatic in stating that no provisions in the Act give rise to a civil cause of action.

Conversely, Luntz et al argue that such concerns regarding Australia becoming excessively litigious are unfounded. For instance, newspaper reports create the impression that victims are continuously being awarded large amounts in damages. ${ }^{107}$ This is in stark contrast to the statistics, which reveal that, for example, large claims in NSW under its compulsory third party motor vehicle system numbered approximately 115 per year in the period 1989 to $1996 .{ }^{108}$ Luntz et al also highlight the research of Wright ${ }^{109}$ that demonstrates there has not been any significant increase in litigation in the period leading to the Ipp reforms. ${ }^{110}$

\section{Measures of Prevention}

The abovementioned concerns regarding floodgates and an overly litigious society, as well as the abovementioned research attempting to dispel such concerns, may reveal what Gaskins referred to as a 'mutual dependence' between private individuals. ${ }^{111}$ There is thus a level of complexity in society that transcends traditional notions of causation, risk and responsibility. Such a complexity signals the need for measures of prevention, rather than measures for victims to obtain compensation. In the following section, steps people and businesses can take to prevent loss or liability, as well as what consumers can do if statutory conditions are breached are provided. In addition some suggestions are provided to avoid the risk of food contamination and to maintain food safety.

\section{Measures Recommended by the ACCC}

According to the ACCC, a consumer can cancel a contract for goods that breach statutory conditions by doing the following:

\footnotetext{
${ }^{107}$ Luntz et al, above n 105, 10.

${ }^{108}$ Ibid.

${ }^{109}$ EW Wright, 'National Trends in Personal Injury Litigation: Before and After "Ipp" (2006) 14 Torts Law Journal 233, 239.

${ }^{110}$ Luntz et al, above n 105, 21.

${ }^{111}$ R Gaskins, 'Regulating Private Law; Socio-Legal Perspectives on the New Zealand Accident Compensation Scheme' (2009) 17 Torts Law Journal 24, 34.
} 
(1) Returning to the seller the goods or providing notice to the seller of the problem within a reasonable time following a consumer having a reasonable opportunity to conduct an inspection of the goods; and

(2) Not getting rid of the goods, or losing or destroying them. ${ }^{112}$

In order, for instance, to receive a refund for defective goods, consumers must exercise caution with the goods they purchase. Consumers must:

(a) take care of the goods in a reasonable manner;

(b) not cause damage to the goods by putting the goods to use in a manner not intended for the goods; and

(c) be able to provide proof of purchase to the seller. ${ }^{113}$

\section{E Consumers to Prevent Food Poisoning}

Much of the content addressed in this article has dealt with managing the results of food contamination, yet there are also a number of proactive steps consumers can take to prevent food poisoning. The following have been outlined by the Victorian government:

(a) Maintaining good personal hygiene by washing and drying hands thoroughly when handling food;

(b) Avoiding a cross-contamination of foods by separating raw foods from readyto-eat foods such as takeaway meals;

(c) Making use of separate, clean utensils, containers and other equipment;

(d) Cooking foods thoroughly, that is, ensuring that foods such as meats and poultry are cooked until the core temperature of the food has reached at least $75^{\circ} \mathrm{C}$;

(e) Avoiding the 'temperature danger zone' which is between $5^{\circ} \mathrm{C}$ and $60^{\circ} \mathrm{C}$ by keeping foods chilled at $5^{\circ} \mathrm{C}$ or lower or keeping foods hot at $60^{\circ} \mathrm{C}$ or higher; and

(f) Avoiding foods that are spoiled, past their use-by date or in containers or packages that are damaged. 114

\section{F Businesses' Response to Food Poisoning Allegations}

While the above have indicated strategies individuals can take to prevent exposure to food contamination attention needs to be given to the responsibilities of businesses if such an unfortunate incident is alleged by a patron. Queensland Health suggests that first, the food business should reassure the patron that they take their complaint

\footnotetext{
112 ACCC, Warranties and Refund: A Guide for Consumers and Business (2009) 8.

${ }^{113}$ Ibid.

${ }^{114}$ Victorian Department of Health, Food Poisoning and How to Prevent It, Food Safety at Home and in the Community (2010) 2-3.
} 
seriously, and that it needs to acquire details from them. ${ }^{115}$ At no time should a food business become apologetic, defensive or indicate that their food is the cause of the patron's illness. Rather, the person receiving the patron's complaint should record the following:

(a) the time and date of the complaint or report of the patron;

(b) the name, address and contact details of the patron;

(c) how many people have fallen ill;

(d) the date and time when the food was consumed at the premises;

(e) what foods were consumed;

(f) what foods the patron suspects have caused the illness; and

(g) Ascertain whether the suspected foods are still in the patron's possession. ${ }^{116}$

\section{G State and Federal Regimes for Proportionate Liability}

Maher, Stone and Sharkey point out that the recent reforms brought about by the $A C L$ have made Australia's consumer protection regime clearer and simpler by replacing the fair trading legislation of the states, bringing the various protections of consumers into harmony. ${ }^{117}$ For example, consumers can now rely on the non-excludable statutory guarantees provided for in the $A C L$. There are, of course, still challenges to face, and the abovementioned authors suggest methods to tackle these challenges.

The state and federal regimes for proportionate liability are an example in point. Under the proportionate liability regime the liability for a defendant's losses are divided among 'concurrent wrongdoers' in accordance with the degree of loss for which each wrongdoer is liable. ${ }^{118}$ The task of apportioning liability for such loss is, of course, one for the courts. Maher, Stone and Sharkey highlight the relevance of proportionate liability to the liability of manufacturers and suppliers of defective products, and the uncertainties pervading the current state and federal regimes. For instance, it is unclear whether or not proportionate liability prevails over indemnities provided for by contract or assignments of liability. Businesses that operate in multiple jurisdictions are thus faced with complexity and uncertainty, by virtue of the fact that there is no certainty as to the enforceability of indemnity clauses contained in the contacts of the business. The flow-on effect of this appears to be an increase in legal costs for businesses. The author therefore suggests that the relevant statutes with respect to proportionate liability should be harmonised to 'improve predictability and lower costs for business'. 119

\footnotetext{
${ }^{115}$ Queensland Health, Food Safety: Fact Sheet (2011) 1.

${ }^{116}$ Ibid.

${ }^{117}$ A Maher, S Stone and J Sharkey, 'Australian Contract Law Reform' (2012) 22

Australian Product Liability Reporter 260, 261.

${ }^{118}$ Ibid 262.

${ }^{119}$ Ibid.
} 


\section{H Alternative Dispute Resolution}

A stronger promotion of alternative dispute resolution (ADR) processes should also be considered. ADR is a term used to describe methods, excluding court proceedings, which can be used to resolve legal disputes. ${ }^{120}$

The common ADR methods are mediation, conciliation and arbitration. Mediation has been a particularly effective method of ADR in Queensland. Cairns ${ }^{121}$ points out that mediation has resulted in a reduction in the amount of civil trials coming before Queensland's courts. Keane J, in an article, cited Harper J's judgment that highlighted the time and cost advantages involved with ADR. ${ }^{122}$ This ties in well with the objectives of the Uniform Civil Procedure Rules 1999 (Qld) which provide for costeffective and fast resolutions for disputes. ${ }^{123}$ As such, the continued promotion of ADR appears to be a worthwhile endeavour.

\section{Conclusion}

This article has explored the issues of liability of manufacturers, wholesalers, processors and retailers for injuries suffered by consumers following exposure to contaminated food/drink products. Various examples of the duty of care, breach, causation, and damage as established in case law have been discussed. The various defences offered through legislation have shown the complexity if interpretation of the concept of liability and redress. Certain measures can be suggested to improve the operation of the $A C L$ by being clear and unequivocal regarding the position of food. The floodgates issue and the concerns regarding the litigiousness of Australian society present a problem in implementing such a recommendation, regardless of how unfounded such concerns might be. Ultimately, prevention may be the best cure, and a number of suggestions have been provided as ways to avoid exposure to the risk in the first instances. The abovementioned preventative steps and courses of action have been recommended by bodies such as the ACCC, Victoria's Department of Health as well as Queensland Health, and should be considered carefully. Additionally, the harmonising of each of the statutes relating to proportionate liability, as well as the promotion of ADR, are worthwhile endeavours.

\footnotetext{
${ }^{120}$ Queensland Law Society, Alternative Dispute Resolution: A Legal Guide to Your Rights and Obligations.

${ }^{121}$ B C Cairns, 'A Review of Some Innovations in Queensland Civil Procedure' (2005) 26 Australian Bar Review 158, 158.

${ }^{122}$ P A Keane, 'Judicial Support for Arbitration in Australia' (2010) 34 Australian Bar Review 1, 2; Gunns Forest Products Pty Ltd v North Insurances Pty Ltd (2004) 13 ANZ Ins Cas 61-606.

${ }^{123}$ Uniform Civil Procedure Rules 1999 (Qld) s 5.
} 